\title{
MIR184 Gene
}

National Cancer Institute

\section{Source}

National Cancer Institute. MIR184 Gene. NCI Thesaurus. Code C81781.

This gene is involved in the regulation of gene expression and plays a role in the development of neuroblastoma. 